
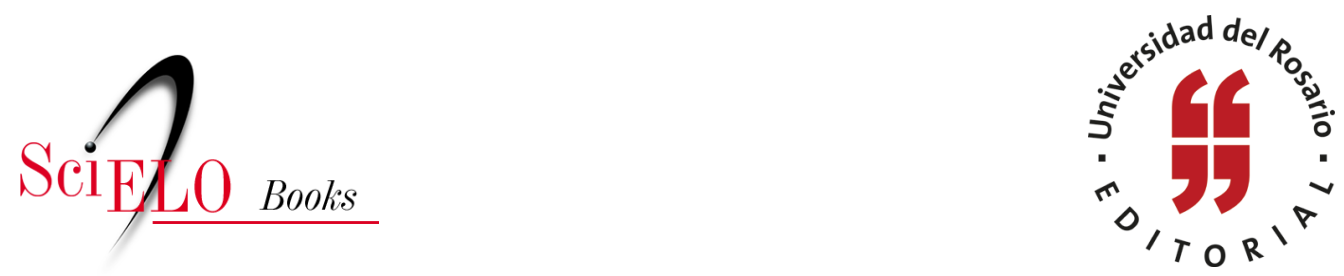

\title{
Las tarjetas de visita racialidad y disciplinamento de ciudadanías blanqueadas en la pardocracia venezolana postindependentista
}

\author{
Beatriz González Stephan
}

\section{SciELO Books / SciELO Livros / SciELO Libros}

GONZÁLEZ STEPHAN, B. Las tarjetas de visita: racialidad y disciplinamento de ciudadanías blanqueadas en la pardocracia venezolana postindependentista. In: SCHUSTER, S., ed. La nación expuesta. Cultura visual y procesos de formación de la nación en América Latina [online]. Bogotá: Editorial Universidad del Rosario, 2014, pp. 123-151. Textos de ciencias humanas collection. ISBN: 978-958-738-524-3. https://doi.org/10.7476/9789587385243.0008.

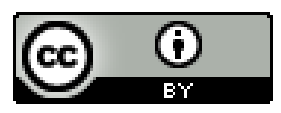

All the contents of this work, except where otherwise noted, is licensed under a Creative Commons Attribution 4.0 International license.

Todo o conteúdo deste trabalho, exceto quando houver ressalva, é publicado sob a licença Creative Commons Atribição 4.0.

Todo el contenido de esta obra, excepto donde se indique lo contrario, está bajo licencia de la licencia Creative Commons Reconocimento 4.0. 


\title{
Las tarjetas de visita: racialidad y disciplinamiento de ciudadanías blanqueadas en la pardocracia venezolana postindependentista
}

\author{
Beatriz González Stephan \\ Rice University
}

Si la fotografía constituye, como lo proponía Walter Benjamin, una suerte de inconsciente óptico, no es solamente porque tiene cierta capacidad para descomponer el movimiento o para capturar alguna situación imprevista, como si ofreciera de vez en cuando algún lapsus, algún fallido visual... Precisamente, ese detalle inesperado se infiltra en el cuadro, en una perspectiva levemente corrida, en un campo visual que ha extendido inexplicablemente sus limites, donde es posible advertir las fisuras de la razón nacional. Paola Cortés-Rocca $(2011,15)$

Gracias a la marca de algo la foto deja de ser cualquiera. Ese algo me ha hecho vibrar, ha provocado en mi un pequeño estremecimiento, un sartori, el paso de un vacio (importa poco que el referente sea irrisorio)...

La incapacidad de nombrar es un buen sintoma de trastorno.

Roland Barthes (1990, 96 y 100)

Las tecnologías y los dispositivos asociados a la visión, a la visualización y a la visibilización no constituyen un espacio desligado de la red de narrativas que configuran el campo autorizado para la construcción de subjetividades. Toda la cuestión de la mirada, como el surgimiento de soportes materiales ligados a la visión, deben ser considerados históricamente, es decir, una particular episteme que posibilita deter- 
minadas maneras de ver ligadas a específicas prácticas sociales y discursivas y, consecuentemente, una determinada matriz que organiza cierto tipo de relaciones entre el observador y lo observado, entre lo visible y lo que no es posible representar. La percepción, por tanto, debe ser atendida como consecuencia de la transformación de prácticas discursivas y no discursivas que reflejan el cambio de las estructuras, de las convenciones, y un campo de posibilidades en el cual el observador va a operar.

Así, la invención de la fotografía fue un momento crucial en el desarrollo de las estructuras de la visión, tanto constitutiva como constituyente del paradigma ocular moderno; ha sido el resultado de una larga serie de experimentos tecnológicos, pero también ha sido posible su invención porque materializa determinadas relaciones entre sujetos y objetos. Ya va siendo lugar común considerar que la modernidad ha privilegiado un régimen epistémico ocularocéntrico, que reduce cada presencia a imagen y a su representación. Un presupuesto de orden social da cuenta de que vivimos dentro de una "cultura fotográfica” y esto nos hace sabernos mirados (soy mirado por la fotografía, decía Lacan), lo cual influye tanto en la pose como en el fotógrafo como supuesto narrador (Silva 1998). Por consiguiente posibilita no solo la aparición de dispositivos ópticos, sino de figuras discursivas organizadas entre relaciones de observador y observado, entre lo visible y lo no visible (Lalvani 1996). De este modo, la fotografía no es solo producto de este paradigma, sino productora de subjetividades que organiza relaciones específicas entre el saber, el poder y los lenguajes del cuerpo: configura horizontes de lo "real" dentro de perspectivas analógicas que hacen hincapié en la relación ontológica entre la representación y el referente externo, ideales para autentificar una autoridad epistémica, sobre todo dentro de los paradigmas de la cultura burguesa del siglo XIX.

También habría que entender los varios sentidos del hecho fotográfico en determinado contexto social, lo que implica colocarlo en una encrucijada de complejas interacciones discursivas con prácticas verbales y no verbales, porque la imagen misma es ya, de por sí, un texto inscrito en lo que se ha llamado "discurso fotográfico", y como cualquier otro discurso es un sitio de intrincadas contiendas intertextuales. Es necesario aclarar, como explican Víctor Burguin y W. J. T. Mitchell, que cada fotografía significa, sobre la base de una pluralidad de códigos y su relación privilegiada con el lenguaje, que una imagen fotográfica funcione como una forma de texto. Del mismo modo, la relación entre fotografía y lenguaje, así como entre imagen y discurso verbal, hay que entenderla simultánea y dialécticamente, es decir, en un espacio donde ninguna de las dos tiene ni privilegio ni un lugar subordinado (Burguin 1982; Mitchell 1994 y 2005). Es lo que Mitchell ha 
acuñado en términos de giro pictórico de nuestra época, como el redescubrimiento poslingüístico y postsemiótico de la pintura en términos de un complejo entramado entre visualidad, aparatos, instituciones, discursos, cuerpos y figuración $(1994,16)$.

Cualquier fotografía es una estructura significativamente selectiva y, por tanto, una estructura incompleta, porque al operar sobre un contexto determinado jerarquiza aquellos aspectos que se necesitan hacer visibles, al tiempo de invisibilizar y ocultar otras zonas. Es un dispositivo que permite ver y hablar desde un heterogéneo ensamblaje de discursos e instituciones, que en su conjunto arman las "curvas de visibilidad y las curvas de enunciación". Al pasar como "documento testimonial", encubre sus propias retóricas tendenciosas, ofreciendo un aura de neutralidad y transparencia de lo representado, oscureciendo a la vez sus propios mecanismos connotativos. Ahí radica su extraordinario poder de convencimiento como máquina productora de ficciones de "verdad" (Lalvani 1996).

Por consiguiente, tanto el hecho fotográfico como la literatura preocupada por regular el disciplinamiento de los cuerpos de las nuevas repúblicas latinoamericanas pertenecen a una matriz de discursos y prácticas que las hacen epistémica e históricamente posibles. Pensar lo fotográfico exactamente no responde a atender a un corpus de imágenes aisladas; necesita reconstruir un complejo tramado de discursos en el que se insertan y preguntarse con qué otras prácticas se relacionan. Del mismo modo, la aparición de una técnica específica de visualización interconecta con otros dispositivos de representación. Además, relaciones coyunturales posibilitan ciertos formatos de la fotografía (para el caso de nuestro interés, el retrato en las carte-de-visite o tarjetas de visita o retratos tarjetas), en estrecha relación con el éxito de las narrativas de control y disciplinamiento (puntualmente, los manuales de urbanidad) a mediados del siglo XIX, en un momento clave de configuración de las nuevas capas medias urbanas en ascenso, aluvionales después de las largas guerras de independencia, y sin duda ansiosas por legitimar y autentificar sus identidades mediante el consumo de una serie de productos novedosos, que bien podían ir desde la adquisición de mercancías suntuarias, nuevos saberes laicos, modales refinados, cultivo de idiomas, destrezas musicales, hasta hacerse su propio retrato fotográfico para distribuirlo entre familiares y amigos a manera de autopromoción.

No es mi objetivo hacer aquí una historia de la fotografía en Venezuela (tarea abordada y aún no agotada por otros investigadores), ${ }^{1}$ ni detenerme prolijamente

1 A la fecha existen algunos libros bastante informativos sobre los inicios de la fotografía en Venezuela, útiles en cuanto a información documental: Origenes de la fotografía en Venezuela (1978); Significación 
en el conocido Manual de urbanidad y buenas maneras del venezolano Manuel Antonio Carreño - al que dediqué algunos ensayos: González-Stephan (1994, 1995a y 1995b) - . Me interesa explorar el campo de representaciones identitarias autorizadas que ponen en circulación un determinado cuerpo y rostro como sujeto ideal de nación moderna, en las no menos difíciles y turbulentas décadas de configuración de la república después de las guerras, hasta su estabilización con el guzmanato (alrededor de 1890), y cómo funcionó la apropiación de ciertas tecnologías de la modernidad noratlántica, en una sociedad poscolonial atravesada por conflictos raciales, tensionada por una heterofobia semántica como legado de una sociedad basada en divisiones de castas, con el peso no muy lejano de la Real Pragmática, que congestionaba la atmósfera social con acuñamientos como gente de calidad, limpios de toda mala raza, limpieza de sangre, calidad de blanco, mezclas infectas y pardos beneméritos. Es decir, cómo operan tanto el retrato fotográfico y el manual en su rol de dispositivos de control, disciplinamiento y tecnologías de individuación en el contexto de una sociedad cuyas diferencias y distancias sociorraciales del anciene regime han sido totalmente desdibujadas para devenir en una sociedad "café con leche" (Wright 1990), atravesada por ansiedades de distinción, sin nítidas demarcaciones étnico-clasistas. En otras palabras, me interesa observar los potenciales funcionamientos y significaciones de una tecnología productora de representaciones visuales en un sociedad mayoritariamente de color (digamos para generalizar parda o no del todo blanca) con aspiraciones a modernizarse o, al menos, de producir cuerpos modernos y distanciarse de los estilos tradicionales y rurales. ${ }^{2}$

histórica de la fotografia (1981) de Josune Dorronsoro; Anotaciones sobre la fotografía venezolana contemporánea (1990) y El retrato en la fotografía venezolana (1993) de María Teresa Boulton; Historia documentada de la fotografía en Venezuela (1995) de Manuel Barroso Alfaro; La fotografía en "El Cojo Ilustrado"(2005) de Gabriel González; El retrato en la colección (2008) de Vasco Szinetar. Sin embargo, resta una gigantesca agenda que atender que supere la mera colección de datos y de materiales. En este aspecto otras regiones del continente han hecho sustanciosos avances.

2 Debo a José Antonio Navarrete la conexión perspicaz entre el consumo de la fotografía (en sus formatos del daguerrotipo, talbotipo, faltbotipo, ambrotipo y tarjetas de visita) y los manuales de conducta como dos discursos que se complementan y apoyan mutuamente en sus funciones disciplinantes y modelatorias de nuevas conductas y cuerpos urbanos para las naciones, al menos como utopía para las élites y las clases medias en ascenso. Ambos son dispositivos que trabajan sobre el control de la mirada. Véase al respecto "Las buenas maneras: fotografía y sujeto burgués en América Latina durante el siglo XIX" (2009). 
Sírvannos rápidamente algunos hitos informativos de interés para apreciar la interconexión entre un determinado momento del desarrollo de la fotografía y ciertas narrativas normatizadoras como tecnologías al servicio, tanto de una producción masiva de bienes como de su consumo democratizado. Un poco de historia conocida:

Cuando el francés Adolphe Disdéri, en 1854, patentó un tipo de fotografía en papel (a diferencia del daguerrotipo, el calotipo o el ambrotipo, mucho más costosos en su producción), donde de una sola toma se podían sacar doce copias en un formato de nueve por seis centímetros, el costo bajó notablemente, amén de que la gente podía disponer de su propio retrato en 48 horas y un tiempo de exposición menos tortuoso que con el daguerrotipo: la carte-de-visite democratizó la nueva tecnología entre las capas medias urbanas tanto en Europa como en las diversas regiones de América Latina, que habían ido ganando bienestar material y se habían convertido en atentos consumidores de los productos que traían los tiempos modernos. También una nueva conciencia de su creciente poder en las ciudades ameritaba su deseo de autentificación de sus subjetividades como individuos. Nada mejor entonces que retratarse como un modo de autoafirmación y proyectar su personalidad dentro de las redes sociales que iban configurando la nueva vida urbana (figuras 1 y 2). ${ }^{3}$

Este tipo de fotografía masificó el género del retrato de la antigua tradición cortesana de la pintura al óleo de la alta cultura. Eran los monarcas, la nobleza, los príncipes y los altos ministros de la Iglesia los sujetos del retrato; pero con el siglo de las revoluciones ( $y$ la francesa fue solo una de ellas, sin descartar otras de orden social, las anticolonialistas y las antiesclavistas), nuevos actores sociales entraron en el escenario político y trajeron consigo una nueva prosperidad económica. Fueron estas clases medias (reconocidas como burguesías), generalmente localizadas en las ciudades, que a la par de incrementar su bienestar material, se encontraron con la necesidad de su validación y reconocimiento social. En palabras de Gisele Freund: "necesidad profunda, de la que el retrato es una manifestación característica, en función directa del esfuerzo de la personalidad para afirmarse y tomar conciencia de sí misma [...] A medida que la necesidad de representación de sí mismo crecía, creaba nuevas formas y nuevas técnicas para satisfacerlas" $(1946,16)$.

3 Hemos trabajado con los archivos fotográficos de la Biblioteca Nacional de Venezuela y de la Fundación Boulton de Caracas. A estas dos instituciones pertenecen la mayor parte de las fotografías aquí seleccionadas, y, por tanto, quiero agradecerles su cortesía por autorizar su reproducción. En caso contrario, se indicará la fuente correspondiente. Como se trata de "tarjetas de presentación", hubo muchas copias de cada foto, y por ello pueden hallarse en varias colecciones. La gran mayoría de ellas no tiene identificación, ni fecha exacta. 

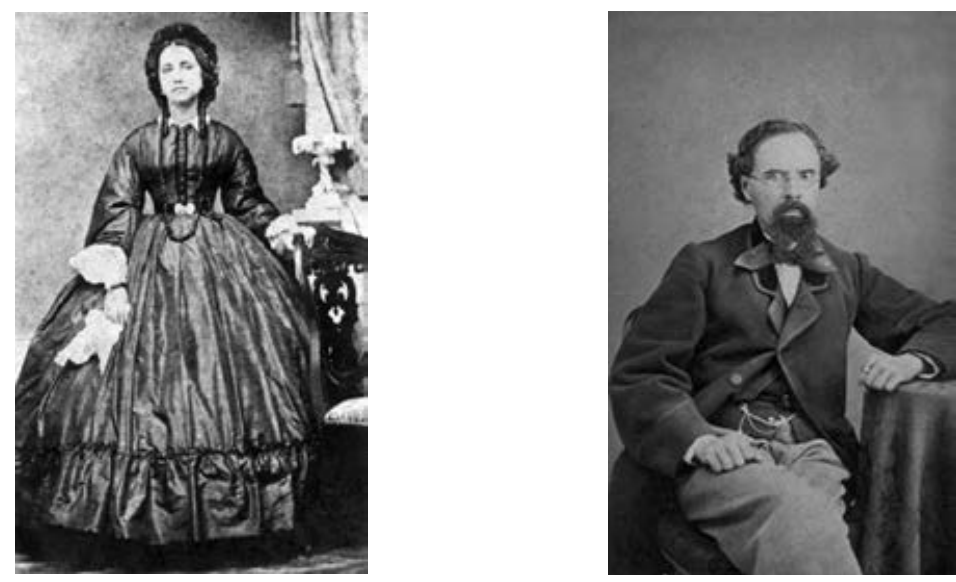

Figuras 1 y 2. Dama y caballero: fotografías del Salón de Próspero Rey, Caracas, 1875

Nota. Las posturas, las expresiones y los decorados tuvieron una reglamentación estandarizada; por lo tanto, el mismo estilo se repitió internacionalmente. Retratarse era entrar en un espacio distintivo, donde la seriedad del rostro y la rigidez del cuerpo marcaban un distanciamiento de los modos relajados de la plebe. Incluso se recomendaba usar telas oscuras, lana, seda y rasos porque acentuaban los aires de prestigio cosmopolita.

Sin embargo, se trataba de una época de transición, en la cual se superponían vestigios del pasado orden colonial no del todo superado, nuevos tiempos con nuevas ideas que traían otras nuevas alteraciones políticas, con protagonistas sociales distintos de las tradicionales élites patricias, sin abolengos y prestigiadas genealogías familiares, y que por tanto no tenían su propia representación identitaria, es decir, no contaban con su propia tradición figurativa. Por consiguiente, tomaron prestados los modos y los estilos prestigiados de la antigua aristocracia europea como sinónimo de modernidad y "civilización”, para distanciarse a su vez del estilo hispánico valorado como retrógrado; pero también de costumbres y usos del antiguo régimen que fueron asociados a una cultura de la "barbarie". La pintura al óleo se dedicó durante esas décadas a elaborar la iconografía épica de la nación, más ocupada en fabricar el rostro de los padres de la patria. Así, el fotógrafo tenía la doble tarea de acomodar a su clientela según la compostura de los nobles, pero ofreciéndoles retratos masificados a precios módicos, de acuerdo con los recursos de esa clase. Sin duda, toda esta contradictoria operación rearticulaba nuevas formas de colonialidad.

En este sentido, las tarjetas de visita ofrecieron a las capas medias el espacio ilusorio o espectral para inscribir sus retratos con un estilo aristocrático. "Esta pequeña burguesía — según Freund— no tiene más que un deseo, no tiende más que a un fin: afirmar su existencia por signos exteriores. La tarea esencial de la fotografía es satisfacer esa necesidad de representación" $(1946,75)$. 
La fotografía construyó individualidades teatralizadas, aparentemente únicas; posibilitó la magnificación del sujeto, al tiempo que permitió la reproducción estereotipada de rostros y poses, y consiguió el efecto de una significativa democratización ilusoria. El estudio fotográfico operaba como un verdadero taller de escenificaciones que facilitaba la teatralización de la personalidad, además de producir el simulacro de un individuo con carácter: a la mano había cortinajes, columnas, balaustradas, paisajes en lontananza, jarrones, mobiliarios, esculturas de pacotilla... y un discreto guardarropa para aquellos que no podían adquirir un buen saco de paño o un mantón de seda. Después de todo, la fotografía respondió a lo que Sylvia Molloy (1994) llamó escopofilia: la apelación compulsiva a lo exhibible o exhibido, la necesaria conversión del mundo en materia de exhibición, su irrefrenable transformación en espectáculo. Mostrar y mostrarse fueron las gramáticas que movieron las prácticas culturales (figuras 3 y 4 ).
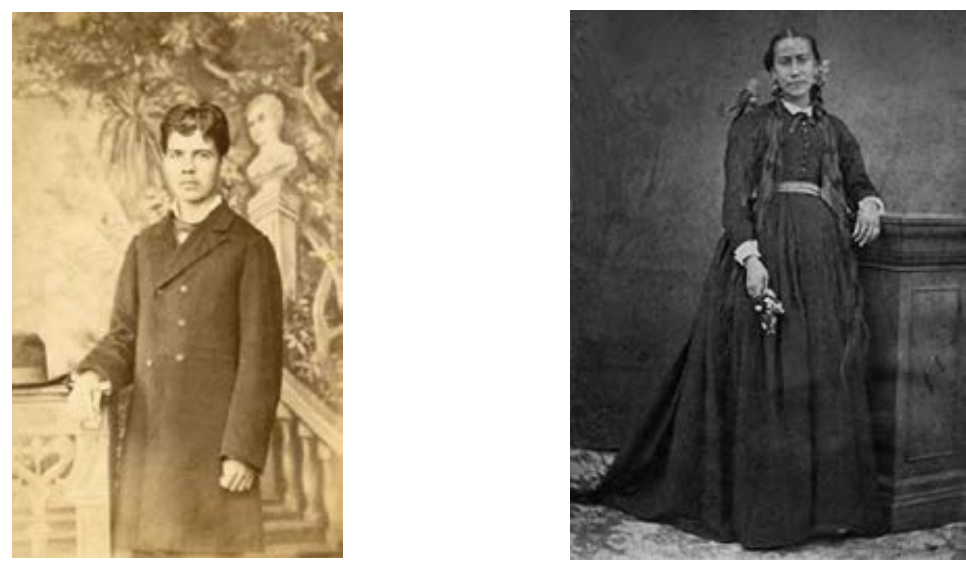

Figuras 3 y 4. Joven y dama anónimos, alrededor de 1876

Nota. La fotografía fue una máquina que invitaba a performar cuerpos y rostros. El individuo se constituía en solo imagen de un otro de sí mismo, una ficción aureática. Pero a la vez estar en la foto era participar de esa modernidad vicaria, parecer ciudadanos de un mundo de pares semejantes, casi europeos, casi blancos. Cuando se trataba del decorado, el detalle grecolatino era muy apreciado.

El retrato en su formato de tarjeta de visita fue producto de un determinado momento de configuración de un sector social que no contaba a la fecha con propias imágenes autorreferenciales; por lo tanto, saqueó y repuso de forma trivial y lamida un viejo archivo de códigos visuales aristocratizantes con nuevas tecnologías que promocionaron ágilmente mecanismos de identidad, con la seriedad y rigidez de la estética neoclásica: fue la popularización y banalización hacia abajo del estilo alto de las artes mayores. En particular para estos sectores medios, y más aún para 
sectores que apenas estaban saliendo de un doble estatuto de subalternización colonial, inscribirse en el género del retrato - aunque fuera con las poses estandarizadas - era construirse primero un cuerpo (de allí la importancia estratégica del retrato de cuerpo entero) y, luego gradualmente, el rostro, que fue monopolizando la escena de la representación, y que la tarjeta de visita supo desarrollar. Así es como el retrato equivalió a la autobiografía social de una clase y compartió con los géneros biográficos el rasgo sustantivo: exhibir una subjetividad y definirse como una "escritura del yo". Irónicamente un “yo" que en su idéntica masificación volvía a desdibujar las especificidades individuales. Ahora bien, el rostro se convirtió en metonimia del cuerpo. En palabras de Paola Cortés-Rocca:

Con la fotografía, el rostro se vuelve emblema de lo que aparece o de lo que se da a ver $[. .$.$] Con el retrato, la fotografía se vuelve escena y participante de una$ oposición que ya no enfrenta apariencias y esencias, sino apariciones o presentificaciones y sentido [...] La fotografía entonces, inaugura un movimiento inverso: ahora se trata de postular, gracias a lo visible, aquello que permanece oculto. $(2011,42$ y 43$)$

Y en este cruce de tradiciones, aunque el aparato mismo (la cámara, la fotografía) eran prácticamente sinónimos del progreso tecnológico, no dejaba de haber en los sujetos retratados una suerte de hibridismo de estilos: por un lado, el consumo de gustos noratlánticos (el saco del joven y los decorados) y, por el otro, ciertos detalles provincianos (las trenzas, los adornos, el lorito), lo que indicaba no solo el abaratamiento de la fotografía, sino su consumo entre sectores cada vez más populares que también deseaban de una u otra forma participar de los bienes de la modernidad, pero que aún estaban fuertemente anclados en tradiciones rurales. Los códigos del retrato, así como entrar en el horizonte ilusorio de este formato, creaban a su vez cuerpos deseables dentro de una ciudadanía disciplinada.

Con el transcurso de las décadas, la relación entre fotografía y preservación de la memoria de familiares y seres queridos se modificó. La tarjeta de visita, aparte de coleccionarse para engrosar álbumes, constituyó más bien una obligación social. En definitiva, ya no importaba su tamaño, tampoco los estilos y las poses (las personas podían tener varias, con diferentes atuendos), lo esencial era tener docenas de ellas. Operaban como tarjetas postales con marcas de identidad que servían para los intercambios comunicacionales entre amigos y conocidos. Fue un pasaporte idóneo para tejer y ampliar circuitos de sociabilidad, pero también para medrar (McElroy 
1985; Massé Zendejas 1998; Silva 1998). En este sentido, es posible que hayan sido un elemento clave en la configuración de las nuevas sociabilidades del espacio público, que ayudaron a diseminar no solo estilos occidentales, sino un régimen de comportamientos regulados y contenidos apropiados para una sociedad de ahorro y de consumo. En este renglón no es casual que las tarjetas con retratos de generales y militares hayan gozado de la mayor popularidad; en estos casos se hacían miles de copias para distribuir, y aparte del gesto coleccionista, la moda del traje militar se extendió durante toda la centuria: precisamente para estos sectores en ascenso irradiaba autoridad y jerarquía, reafirmaba virilidades fuertes, pero por sobre todo vendía la imagen de una masculinidad blanca euroccidental. ${ }^{4} \mathrm{~A}$ la vez, la foto con este traje permitía una curiosa fantasía: la igualación del hombre insignificante con los generales, y a estos, con los héroes nacionales. Después de todo, eran los tiempos del simulacro y el poder de las apariencias.

A la par y en una dinámica simétricamente proporcional al éxito de las tarjetas de visita en la capital francesa, del otro lado del Atlántico, el venezolano Manuel Antonio Carreño (Caracas 1812-París 1874) publicaba también en 1854, en forma de libro, su Manual de urbanidad y buenas maneras para uso de la juventud de ambos sexos; en el cual se encuentran las principales reglas de civilidad y etiqueta que deben observarse en las diversas situaciones sociales, simultáneamente en Caracas y en Nueva York. Hombre de empresa, comerciante, editor, traductor, profesor de piano (fue el padre y maestro de la famosa pianista Teresa Carreño) y director de

4 Fue Disdéri quien convirtió la fotografía en definitivamente popular. El daguerrotipo era aún costoso y no completamente accesible para las clases medias. Reemplazó la placa metálica por el negativo en vidrio, inventado hacía tiempo, y pudo hacer un cliché y entregar una docena de copias por un precio cinco veces menor. Pero fue una circunstancia muy especial que lo llevó al éxito: Napoleón III, paseando con su tropa por las avenidas, se detuvo en el taller de Disdéri para hacerse retratar; después de él, todo el ejército... A partir de ese momento cundió el delirio no solo de la moda de las tarjetas, sino también parecerse al emperador. Estas cruzaron el Atlántico e impusieron la moda militar (Freund 1946; McCauley 1985). La adquisición de un uniforme ya venía desde los tiempos de las guerras emancipadoras. La soldadesca era pobrísima, en su mayoría mulatos y esclavos, que terminaban comprando los uniformes de las legiones inglesas. Por tanto, lo que se impuso fue el uniforme estilo inglés, luego sustituido por el estilo napoleónico, y más tarde por el prusiano. Entonces para la población de color vestirse así no solo en esos años, sino también luego en la república era de alguna forma destacarse socialmente y de paso blanquearse (Abreu Xavier 2011). 
establecimientos educativos, logró divulgar su Manual en España, Cuba y Puerto Rico, con tanto éxito que al año siguiente el texto vio nuevas reimpresiones en Madrid y en Estados Unidos. Sin duda, no solo los manuales estaban de moda entre estos sectores medios que abrevaban de cualquier medio para transformar sus antiguos hábitos provincianos en otros más acordes con su estatus económico, sino que el Manual de Carreño, por su estilo más moderno y secular, fue el que alcanzó mayor difusión y acogida internacional.

Su novedad consistió en reconocer el potencial que ofrecía el cuerpo como capital simbólico si se le trabajaba y disciplinaba más que el alma, convirtiéndolo en el centro decisivo del éxito y de la distinción social. En este sentido, Carreño desacralizaba el cuerpo: ya no era asunto ni de Dios ni de las genealogías, tampoco de la "limpieza de sangre" ni de la suerte de las personas; ofrecía una nueva concepción del individuo al comprender la subjetividad anclada en un cuerpo anatomizable (partes que pueden ser trabajadas con la técnica apropiada), factible de ser transformado si se tenía voluntad y método. Tener hábitos, repetir reglas de contención, aseo, limpieza y la moderación exterior de las pasiones dentro de una nueva economía del tiempo es la retórica que alimenta su manual: "Las costumbres domésticas, a fuerza de la diaria y constante repetición de unos mismos actos llegan a adquirir sobre el hombre un imperio de todo punto irresistible, que le domina siempre, que se sobrepone al conocimiento especulativo de sus deberes, que forma al fin en él una segunda voluntady le somete a movimientos puramente maquinales" (Carreño s. f., 300. Las cursivas son de la autora). ${ }^{5}$

Efectivamente la clave del éxito ahora dependía del self, del individuo mismo si seguía al pie de la letra la prescripción de las reglas que él ofrecía en su compendio. Esto fue un parteaguas para una sociedad regida, hasta no hacía mucho, por estrictas

5 Vale la pena destacar algunos detalles de la vida familiar de Manuel Antonio Carreño, que contextualizan el lugar desde donde articuló sus aportes. En primer lugar, descendió de una familia de expósitos. Tanto el padre como el tío, Cayetano (1774) y Simón, fueron hijos abandonados por una señorita criolla. Por tanto, fueron "blancos de orilla". Cayetano Carreño fue músico de la catedral. Luego Manuel Antonio contrajo nupcias con una de las sobrinas de Simón Bolívar, con apellidos encumbrados pero empobrecida. No realizó estudios universitarios, y se dedicó a varios oficios de acuerdo con las oportunidades que se le presentaron. Podemos inferir que el mismo Carreño entendió que si no era por su propio esfuerzo no sobreviviría. Familiarizado con la música, escribió también un curso completo de ejercicios diarios para piano, que puso a prueba con su hija Teresita. Indudablemente, vio en ella cualidades que se podían desarrollar, y la convirtió desde muy joven en niña prodigio, y luego en la pianista más famosa del mundo entre 1863 y 1917, cuando muere en Nueva York. El lado perverso es que también vio la genialidad de su hija como un capital humano explotable (Alcibíades 2005). 
reglas basadas en una pigmentocracia, donde la presión de los pardos por ser reconocidos y aceptados nunca tuvo demasiada suerte, aunque la primera Constitución de 1811 declaraba la igualdad de todos los ciudadanos "libres" y la eliminación de privilegios basados en el color. El giro se desplazaba ahora hacia cuerpos entrenados en simular la "suavidad" y "encantos" de aquellas élites de antaño. No es de extrañar entonces que se le reconozca, hasta hoy en día con sus miles de ediciones, como el Manual por excelencia.

Por otra parte, Carreño venía publicando desde la década de 1840 en los periódicos locales (El Diario de Avisos, Correo de Caracas, El Venezolano) una serie de artículos que apuntaban a la necesidad de otros modales más cónsonos con la naciente vida urbana, amén de promocionar la apertura de su establecimiento escolar (el Colegio de Roscio en 1841) que ofrecía asignaturas para las nuevas profesiones. Allí las jóvenes generaciones de caraqueños podían estudiar dentro de un clima de afecto y complicidad, sin el rigor punitivo del antiguo régimen colonial, materias como geografía, historia, inglés, francés, aritmética, matemáticas, dibujo, música, e incluso clases de gimnasia y de buenas maneras. Carreño no fue él mismo un maestro; no se dedicó a la pedagogía públicamente, pero sí entendió prontamente que los tiempos de la nueva república abrían un espacio aprovechable para la avalancha de sectores que salían de la turbamulta de la guerras sin los modales apropiados, y que el régimen de los criollos mantuanos había entrado en crisis. Eran tiempos desconocidos, cuando la pérdida de los códigos que estratificaban el antiguo orden facilitaba la construcción de un individuo desconocido pero con posibilidades, paradójicamente reintroduciendo modos y estilos señoriales. ${ }^{6}$

El caso es que cuando el fotógrafo Próspero Rey, que ya tenía en Caracas un concurrido estudio fotográfico, introdujo las carte de visite en 1862 después de un viaje a Francia donde el mismo Disdéri lo retrató, la población de Caracas ya esta-

6 En cuanto se organizó la vida cívica al término de las guerras, hubo una extraordinaria preocupación por normar lo que debía ser ese ciudadano. No fueron pocos los textos que se publicaron, amén de ser asignatura obligatoria en las escuelas: muy tempranamente Manual politico del venezolano (1820?), de Francisco Javier Yanes; Catecismo de urbanidad civil y cristiana para uso de las escuelas (1833), de Santiago Delgado de Jesús y María; De las obligaciones del hombre (1840), de Domingo Quintero; El libro de la juventud o conocimientos esenciales para una buena educación (1840), sin autor; Lecciones de buena crianza, moral y mundo, o educación popular (1841), de Feliciano Montenegro; Catecismo de moral (1841), de Joaquín Lorenzo Villanueva; Manual de la buena compañia, o el amigo de la civilidad, del buen tono y de la decencia (1851), de M. A. Menéndez. Por consiguiente, el Manual de Carreño se insertó no solo en una tradición establecida, sino que perspicazmente pudo marcar una diferencia, distanciarse de ser un "catecismo" y acercarse a un sentido más pragmático, un "manual". 
ba lista para posar de acuerdo con las reglas que las nuevas técnicas importaban y tomarse la foto con todo el rigor de la ocasión y aparecer etiquetados con toda la empacadura y sobriedad que exigía la nueva moda (figura 5).

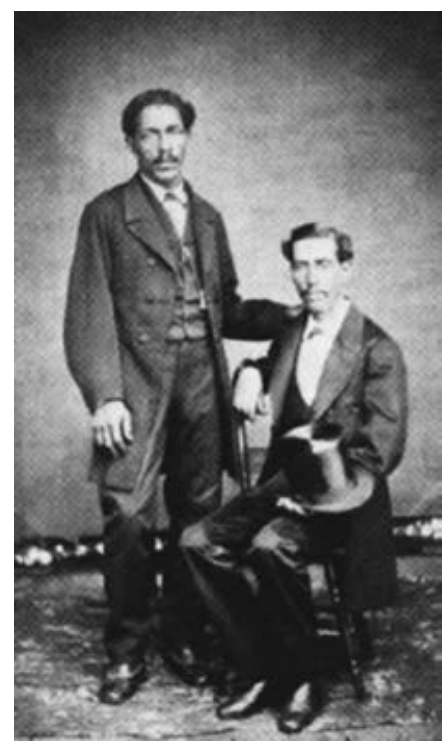

Figura 5. Anónimo, La Guaira, 1871

Nota. Cortesía de la Fundación para la Cultura Urbana. El desaseo, la barba larga, ir descalzo o en alpargatas, escupir, hablar gritado, comer con las manos, el poncho, el juego, las borracheras eran las costumbres de los mulatos, negros y campesinos. Para el retrato el vestuario era esencial, zapato cerrado y sombrero Pumpá (por eso está en primer plano) y cara de circunstancia. La gravedad de la expresión significaba hombre de éxito y "gente decente". Por tanto, cambiar los modales era una estrategia de distinción.

Recordemos algunas normas del Manual en torno a la contención de gestos notablemente expresivos y excrecencias corporales, lo que por otra parte se conjugó a la perfección con las poses exigidas para los retratos:

Todas nuestras relaciones deben comenzar bajo la atmósfera de la más severa etiqueta [...] No acostumbremos llevar la mano a la cabeza, ni introducirla por debajo de la ropa con ningún objeto y menos con el de rascarnos. También son actos asquerosos e inciviles el eructar, el limpiarse los labios con las manos después de haber escupido, y sobre todo el mismo acto de escupir [...] Los vellos que nacen en la parte interior de la nariz deben recortarse cada vez que crezcan hasta asomarse por fuera [...] Jamás empleemos los dedos para limpiarnos los ojos, los oídos, los dientes, ni mucho menos las narices [...] No permitamos nunca que el sudor de nuestro rostro se eche de ver por los demás. (Carreño s. f., 55-60) 
Está de más indicar que los manuales, junto a otras prácticas, ejercieron una cadena serializada de micropolíticas de disciplinamiento, que normalizaron e invisibilizaron los mecanismos abiertamente represivos del control y suavizaron la implementación de reglas de conducta que fueron encorsetando cuerpos sociales como "cuerpos civilizados" a diferencia de los "cuerpos bárbaros". Veremos más adelante la importancia en el retrato de mostrar las manos con las uñas limpias y recortadas. También destaquemos el énfasis que hacía el Manual en cuanto al traje y su porte:

La diversidad en las piezas de que consta el traje, en las telas que para ellas se eligen, y en las formas que les da la moda y el gusto de cada cual, es una prueba evidente de que nuestros vestidos no tienen por único objeto el cubrir el cuerpo de manera honesta y decente, sino también contribuir á hacer agradable nuestra persona, por medio de una elegante exterioridad [...] la manera de llevar el traje depende en mucha parte su lucimiento, pues en un cuerpo cuyos movimientos sean toscos y desairados, las mejores telas, las mejores formas y los más ricos adornos perderán todo su mérito. (Carreño s. f., 326)

En palabras de José Antonio Navarrete, "el Manual es en su letra simétrico a las características dominantes en el retrato de tipo burgués correspondiente a la fotografía decimonónica; de otro modo, la fotografía realizó de maravilla la 'masificación' visual de las reglas de la primera entre los sectores medios y altos del continente, principalmente urbanos" $(2009,41)$. De otro modo y a la inversa, el discurso del Manual está articulado sobre la base de la "mirada panóptica": la conciencia de que el sujeto ahora es un cuerpo público que será visto permanentemente por los demás y que la vida social es una puesta en escena sin descanso. La mirada censora, al modo de una cámara oculta, se hace presente tanto en espacios privados como en públicos. Carreño recomendaba incluso que "al despojarnos de nuestros vestidos para entrar en la cama, hagámoslo con honesto recato, y de manera que en ningún momento aparezcamos descubiertos, ni ante los demás ni ante nuestra propia vista" (Carreño s. f., 82. Las cursivas son de la autora), destaca la interconexión de esta retórica con lo que antes señalamos como "cultura fotográfica". Por un lado, sistematizar el autocontrol y la autocensura como parte del nuevo régimen de micropolíticas policiales no punitivas y, por el otro, el hedonismo narcisista y voyerista que entrañaba el mirar y ser mirado. ${ }^{7}$

Una lectura atenta del Manual de Carreño que atienda el nivel semántico del lenguaje verá que entre el léxico más reiterado están las expresiones “no llamar la atención”, “ser observado”, "apartar nuestra 
Tanto manuales como tarjetas de visita interconectaron y vertebraron los dos regímenes escópicos dominantes del siglo: el régimen panóptico que diseminó un ojo censor vigilante desde una implícita estructura totalitaria y jerárquica, para difundir un cuerpo de pulsiones reguladas para una economía del ahorro y producción de capital. Y el régimen panorámico, que dio lugar a una cultura de prácticas escópicas más democratizadoras y horizontales (como la fotografía, los globos aerostáticos, el diorama, los estereoscopios), que permitieron la visibilidad del mundo a las grandes mayorías.

La irónica coincidencia de fechas entre el Manual de Carreño y la invención de las cartes de visites por Disdéri, en 1854, puso de relieve la centralidad fenomenológica del diseño del cuerpo como lugar privilegiado de prácticas de poder a micro y gran escala y la visibilidad de ese cuerpo como centro neurálgico de ciudadanías legales o patológicas. Pero también la sobreabundancia que controla un campo de visibilidad, organiza sus propios discursos antiocularocéntricos de cuerpos que no son figurables en el marco de representación.

Recapitulemos hasta aquí: los retratos de las tarjetas de visita se produjeron por millones en todas las regiones del mundo y reprodujeron las mismas poses, vestuario, decorado, seriedad, rigidez y solemnidad. Tener su propio retrato era no solo participar, aunque vicariamente, del proceso de modernización material, sino también construirse espectacularmente como sujeto individuado, y configurarse visiblemente a través de estas tecnologías dentro de una ilusoria comunidad cosmopolita de pares iguales. En este sentido, operó como un dispositivo que producía el efecto literal de nuevas objetividades, y por tanto una "verdad" que descansaba en el poder escópico de las formas.

La revisión de la gigantesca masa de estas imágenes que configura el archivo del retrato de las cartes de visite, no solo en el ámbito latinoamericano, sino en el regional - para el caso, las 2717 fotografías revisadas en la Biblioteca Nacional de Venezuela y en la Fundación Boulton en Caracas— no nos dicen nada particularmente

vista," "nada hemos visto", “alcancemos a ver a una persona”, "dirigir miradas escudriñadoras," "es incivil fijar la vista en las personas extrañas", "ni es decente ni bien visto que una mujer aparezca en la ventana", "no fijemos detenidamente la vista en las personas que encontramos", "ni volvamos la cara para mirar"... En definitiva, lo que se desprende es que ha surgido una sociedad para mirar y exponerse, o al revés, que estos manuales han sido escritos teniendo presentes el daguerrotipo y la cámara fotográfica. 
distinto de lo que ya sabemos o lo que debemos ver: todos los elementos guardan cuidadosa armonía para que veamos "esto": la performancia de respetabilidad de los individuos de una clase que es de cierto modo la misma en todas partes (véanse figuras 1 a 5). Barthes lo llama el studium — que "viene siendo un contrato firmado entre creadores y consumidores [...] un mismo interés vago, liso, irresponsable, que se tiene por espectáculos, vestidos o libros que encontramos 'bien'” (1990, 66 y 67), y que más adelante califica como un género "unario"-, "porque transforma la 'realidad' sin desdoblarla, sin ninguna dualidad, ninguna distubancia" (Barthes 1999,85 ), porque a la postre todos los sujetos resultan iguales: el mismo operativo contradictoriamente lima las diferencias, incluso las de entre centros y periferias. Sin embargo, me tropiezo con otra serie de retratos (figuras 6,7 y 8), de infantes tomados por distintos estudios fotográficos de la época, y algo perturba mi percepción.
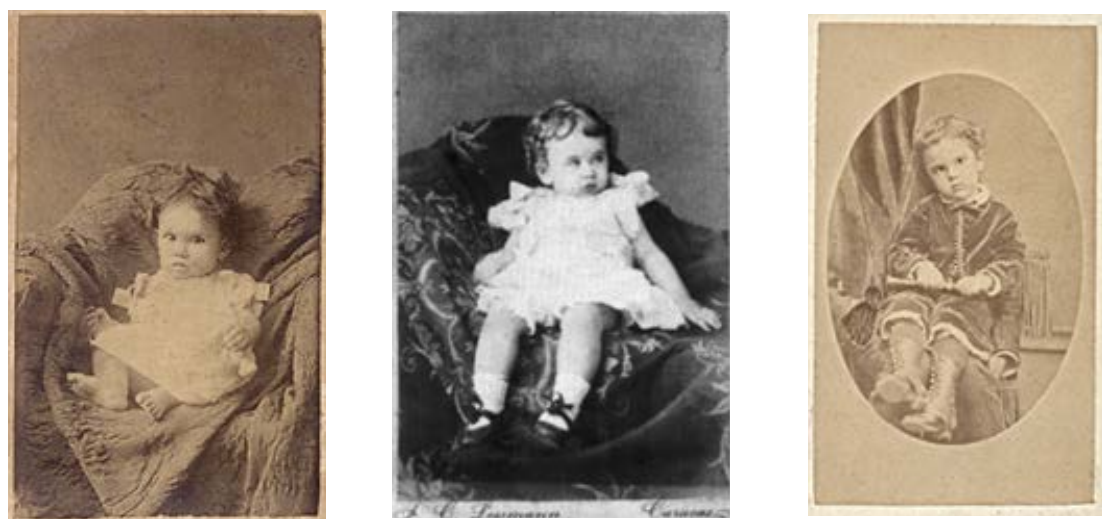

Figuras 6, 7 y 8 . Niñas y niño anónimos, respectivamente de 1868, 1876 y 1893, esta última del taller de F.C. Lessmann

Nota. La composición habitual es que los niños estuviesen sostenidos por sus nanas o nodrizas por lo general negras esclavas o mulatas. El caso venezolano es inusual, estas aparecen recubiertas. La mirada no entrenada no percibe esta omisión. Después de revisar muchos retratos de este género, incluso por regiones, aparece la difference, en el sentido derridiano de un desplazamiento significativo del signo: el error de no haber cubierto parte de las piernas y de la mano que sostiene al niño. Esa falla ha permitido leer el archivo en su reverso, cuestionarlo y empezar a dudar de su transparencia.

Precisamente aquello que no debe ser visto, ese algo que no debe salir en la foto: lo que está encubierto, lo que está “tapado”. Ese detalle que se escapa de la cámara, o que se cuela como un espectro dentro del cuadro, altera la gramática reguladora de la mirada. Es el punctum, para seguir con Barthes, un punto de fuga que me hiere y descoloca. Revelo una copresencia inquietante: la persona o, más puntualmente, la cargadora o doméstica que según estos casos debía cargar al niño o niña está presente para sostenerlo, pero cubierta con una frazada para borrarla de la foto. 
Efectivamente, ese bulto que no vemos a primera vista, es lo que debe desaparecer, es lo borrado del campo histórico de visibilidad. Aquí el retrato naturaliza, con una dudosa transparencia, la imagen independiente del individuo (aunque se trate de infantes) como sujetos libres de toda dependencia. De momento pone en cuestión ese self que se quiere proyectar; pero también lo que mencionaba antes, una matriz de normas disciplinarias que culturalmente regula lo que debe ser reprimido y no dicho. Es precisamente lo que no está en el campo de visibilidad, su negativo, lo que debe ser interrogado.

El género de retratos de niños (incluso la moda de retratarlos muertos para guardar su memoria como si estuviesen vivos) fue muy abundante en todas las regiones de América Latina, y la norma era que estuviesen siempre acompañados, precisamente para sostenerlos. Por tanto, infiero que el ojo que mira este tipo de fotografías se ha ido alienando para ver esta imagen solo desde su lado "positivo" y, por consiguiente, reproducir los silencios enunciativos de su "negativo". En otras palabras, los críticos e investigadores de la fotografía (al menos en Venezuela) no han advertido este detalle.

Ahora comparo este tipo de retrato con otros semejantes de otras regiones (por ejemplo, de Brasil y Perú) y advierto que hemos sido entrenados para ver con cierta normalidad a estos niños blancos de las clases señoriales y burguesas con sus sirvientas de color, negras esclavas e indígenas (figuras 9 y 10 ).

Ellas están ahí como presencias desubjetivadas, y no como retratos de individuos; el centro lo ocupa el benjamín de la familia. Aunque la foto de Villela está tomada en los años 1860 en Brasil, y la esclava negra ocupa el centro de la imagen y pareciera la figura principal trajeada con vestido y manto de seda, habla más bien de la riqueza y opulencia de sus amos que la exhiben como su trofeo. Ellos están ausentes, pero el pequeño benjamín a su lado, en su insignificancia lateral, es quien la posee, sin violencia, pero estando en lugar del amo, y el gesto afectuoso de abrazarla edulcora el lado tortuoso y oscuro de la esclavitud. La circulación masiva de este tipo de tarjetas de visita, sobre todo en Europa, atenuaba los debates sobre el antiesclavismo y mostraba las bondades de la institución. Es decir, la preservación de esta institución siempre y cuando los amos fuesen gentiles. Desde luego, el detalle de las manos cerradas y callosas de la cargadora es posible que dijera lo contrario...

La proliferación de estas tarjetas con niños blancos y nanas esclavas no fue inocente; se produjo para la comunidad internacional cuando se intensificó la demanda de recursos naturales de América Latina y la necesidad de mano de obra barata, dentro del clima de debates y movimientos antiesclavistas. 

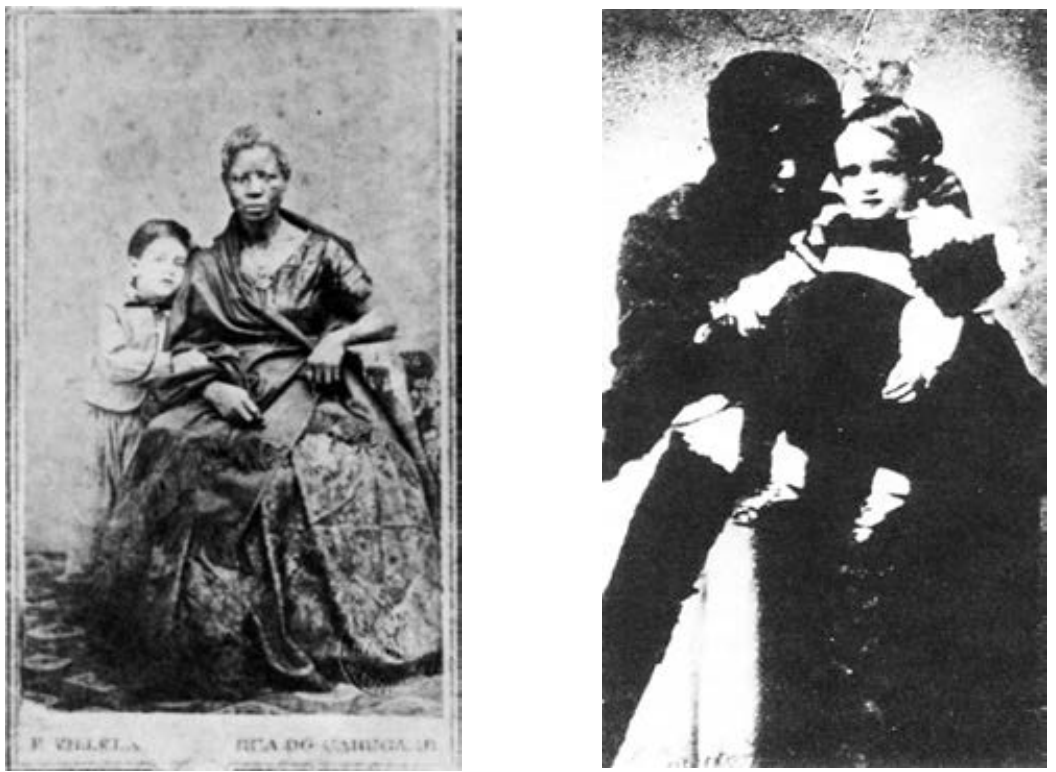

Figuras 9y 10. Niño con ama esclava, Recife, Brasil, 1860, de Joao Ferreira Villela; e india con niño, Perú, alrededor de 1868

Fuente: cortesía de Robert M. Levine.

Aunque son retratos, no se proponen como rostros de sujetos individuados; de hecho, la fisonomía del rostro interesa poco, y en algunos casos, como el del Perú, puede quedar incluso sombreado. Aparte de sostener a la criatura, el retrato apuesta a una ilusoria y no menos tensa convivencia con las diferencias étnicas: el sombreado accidental del rostro de la cargadora indígena ilumina, paradójicamente, quién de los dos protagonistas podía ingresar en la escena visible. Aquí, en un doble movimiento, quizás por torpeza del fotógrafo, la cámara incluye y margina a la vez, poniendo al descubierto las insuficiencias de un lenguaje para representar con nitidez y sin ambigüedades la autorización de lo representable. Es un fallido indicador del deseo de incluir claramente y ocultar. También no deja de revelar la situación contradictoria de estas burguesías al desear ser modernas, pero conservando el orden colonial.

Volviendo al caso venezolano, lo que más me interesa ahora es el negativo del retrato, lo no representado; no solo el rostro sin duda no blanco de la cargadora, sino el tramado de ansiedades raciales no explícitas de la sociedad venezolana postindependentista, que oculta sus contradicciones a la hora de construir su autorrepresentación a través de los lenguajes del progreso tecnológico, lo que sin 
duda resituaba simbólicamente al retratado dentro de las coordenadas de una modernidad europea y blanca.

Me pregunté entonces qué había detrás o debajo de esa "gente decente" que se sentía incómoda con la copresencia de ese otro no blanco que no debía aparecer en la foto, ni siquiera sombreado. No estar junto a, eliminar la posibilidad de una confusión de presencias contiguas precisamente por las difusas fronteras de la diferencia racial, o porque casi todos tenían algo más de "café" o de "leche" en la piel... Sacar a la servidumbre de color del campo visible —o al amigo algo más oscuro de piel- podía crear el efecto de un grupo social moderno, homogéneo y desracializado e inclusive jugar a la democracia racial (figura 11).

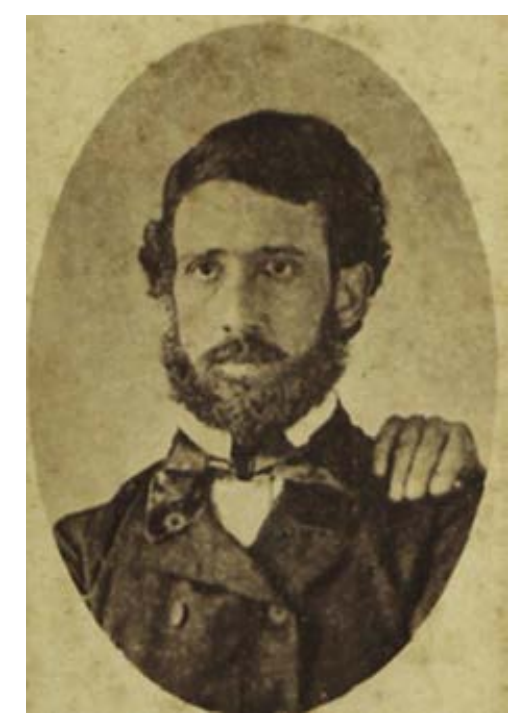

Figura 11. Caballero, alrededor de 1869

Nota. Ya desde las primeras décadas de la república, con el primer gobierno de José Antonio Páez y la inmensa riqueza que trajo la exportación del café, independientemente del inestable clima político, la sociedad caraqueña fue uno de los grupos urbanos del continente que más visiblemente estuvieron a la vanguardia de las modas europeas; se caracterizó por su exquisito refinamiento y gran consumo. Una mala u "oscura" compañía podía desmerecer de la elegancia de sus apariencias. Probablemente este caballero se había retratado con un amigo, que luego le resultó poco conveniente...

Dentro del orden colonial, la dicotomía racial de opuestos se establecía a partir de nociones relativamente claras, donde las divisiones se configuraban en torno a categorías nítidas de blanco/libre y negro/esclavo. Las oposiciones pueden ser epistémicamente formuladas dentro del paradigma "blanco" que se opone a un “otro" no blanco. Pero era más difícil construir oposiciones dentro de una sociedad mestiza, mulata o parda, donde las dinámicas del esquema sociorracial aparecían 
desdibujadas o, al menos, sin una clara y suficiente demarcación. Las categorías racialmente intermedias, amén de trastocar el orden estrictamente colonial, produjeron en algunas zonas complicadas alteraciones sociales e incluso rebeliones de cierta importancia.

En el caso de la sociedad venezolana, la categoría de "pardo" englobaba una serie variopinta de grupos sociales subalternos principalmente no blancos. Pero esta misma era sumamente heterogénea, porque los podía haber libres, manumisos o esclavos; más oscuros o muy claros; pobres o en una situación económica prominente, y ya hacia finales del periodo colonial entre 1790 y 1811 entre los pardos se fue configurando una casta de "pardos beneméritos", rica, educada, dedicada al comercio y a oficios artesanales, que los había colocado en una situación no solo de bienestar, sino indispensable para los estilos de vida de los blancos criollos. Por ejemplo, la profesión de médico era ejercida por pardos. Obviamente, estos sectores presionaron sustancialmente a la Corona para adquirir títulos nobiliarios que los "dispensasen" de la "calidad de pardo" (es lo que se conoció como la Real Cédula de Gracias al Sacar aprobada en 1796), cédula que los podía "limpiar de toda mala raza". Algunos pocos obtuvieron incluso el título de "don", ante la alarma de las élites, que a su vez presionaron por su lado para suspenderla (Pérez Vila 1986; Gómez 2004; Quintero 2006; Sosa Cárdenas 2010). Estos pardos habían sufrido un proceso de blanqueamiento tanto literal como simbólico, y sentían el derecho de poder asimilarse a las élites. Sin entrar en más detalles, este grupo social —con mayor o menor fortuna económica o educación, con una pigmentación más o menos clara u oscura- entró en la escena política y social a partir de 1830 . El término pardo, como el régimen de castas, quedó abolido constitucionalmente. Sin embargo, pienso que pocas décadas de vida republicana no pudieron hacer desaparecer estructuras afectivas y sensibilidades basadas en diferencias raciales, que aparecieron desdibujadas dentro de la nueva atmósfera democrática y con nuevas reglas de promoción social.

Resulta sintomático - para volver a nuestro tema- que el Manual de Carreño haya sido precisamente concebido en un contexto con una densa trayectoria de reglamentaciones que jerarquizaban racialmente a la gente; por tanto, ofrecía la llave de la distinción y medro social a partir del dominio del lenguaje del cuerpo que, al modificar las formas, de alguna manera disipaba el color de la piel. Esto podría explicar cómo su primera recepción exitosa (Cuba, Puerto Rico y Nueva York) tuvo que ver con sociedades atravesadas por el estigma de la colonialidad. No olvidemos que también la teatralización de fisonomías y escenarios que ofrecían 
las tarjetas de visita transfiguraban al sujeto y lo convertían en un individuo que lo sacaba de su contexto ordinario y lo colocaba en el terreno de una subjetivación ficticia, donde los mismos retoques de la tecnología en las tarjetas artísticas lo rejuvenecían, atenuaban defectos, embellecían y blanqueaban (véanse las figuras 3 y 5). Sin duda, el efecto de verosimilitud de este nuevo medio podía hacer pasar el simulacro por realidad; es decir, los retratos que llenaban los álbumes construyeron una comunidad de caraqueños blanqueados.

El contexto histórico de la Venezuela postindependentista, que se inauguró como república en 1830, con el gobierno centralista y conservador del general José Antonio Páez (conocido popularmente con los apodos de "Centauro de los Llanos", “el León de Payara," “el Rey de los Araguatos”), presentaba lo siguiente: Páez recibía un país completamente diezmado y en ruinas. En palabras del historiador Elías Pino Iturrieta, el huracán de las guerras tan prolongadas contra el imperio provocó una metamorfosis de la sociedad sin precedentes, que la dejó irreconocible, no solo por la disminución general de la población, sino por la destrucción de las antiguas heredades y la casi desaparición de sus dueños, es decir, la extinción de los blancos patricios. Lo que asomó después de las guerras fue la irrupción de la "plebe" (Pino Iturrieta 2001), lo que traducimos como la presencia de un aluvión indiferenciado de nuevos sectores salidos de la nada, sin apellidos, en muchos casos sin riquezas, sin antecedentes, donde se podían dar la mano tanto los blancos pobres o de "orilla" (como el mismo Carreño y su esposa Clorinda García de Sena y Toro, sobrina de Simón Bolívar y del marqués del Toro), artesanos, funcionarios, empleados, comerciantes, banqueros inmigrantes, que se fueron acomodando principalmente con la nueva economía del café e importación de artículos suntuarios, así como una clase militar surgida de las guerras y que configuró la élite del poder político junto con esta burguesía comercial. ${ }^{8}$

8 Investigaciones más recientes (Pérez Vila 1986) han demostrado que entre las castas de finales de la Colonia, los pardos y los mestizos libres fueron configurando como clase artesanal una protoclase media urbana que habría de perfilarse como tal en las primeras décadas de la república. Parecida al sector industrial moderno, obtenían su fuerza porque desarrollaron oficios indispensables para la sociedad, como zapateros, tejedores, carpinteros, albañiles, ebanistas, herreros, pintores, cereros, plateros, canteros, sombrereros, ceramistas, armeros, fabricantes de instrumentos musicales y otros oficios más, sin los cuales la clase señorial no pudo sobrevivir. No habría que esperar hasta el guzmanato ni finales del siglo XIX para que la sociedad venezolana se convirtiera en moderna clientela de bienes suntuarios. Desde inicios de la centuria, aunque Caracas era una ciudad modesta y con aires coloniales, la sociedad que la integraba había desarrollado gustos sofisticados y europeos. 
El nuevo mapa que se perfiló, básicamente en las ciudades, no indicaba que todos fueran necesariamente blancos. Por el contrario, en su mayoría fue una sociedad de color, "café con leche", que ocupó los vacíos dejados por la antigua estratificación social y con afanes de remedarla en sus gustos, porque las estructuras en cuanto a la tenencia de la tierra y mano de obra seguían casi inalteradas, incluso después de la abolición de la esclavitud, en 1854. Además, habría que tener presente que, si para mediados de siglo la población de la capital era de 45.000 habitantes aproximadamente, 13.000 eran aún esclavos. Y nada más que en Caracas se concentraba el $58 \%$ de esta masa laboral (entre esclava y manumisa), y el $85 \%$ era de color (entendemos negros, mulatos, zambos y pardos); por lo tanto, el grupo de blancos constituía una minoría amenazada. Y más si tenemos presente que, ya para los años de 1844 surgieron en Caracas clubs de pardos libres y sirvientes de color que clamaban por la abolición de la esclavitud y animaban a las masas a la distribución de bienes y la decapitación de los pocos blancos (Pino Iturrieta 2001). El clima social y político de esas décadas, que culminó no solo con la Guerra Federal (1859-1863), sino con la Revolución Amarilla (1869-1870), encabezada por Antonio Guzmán Blanco, estuvo salpimentado por sistemáticas rebeliones, que desde diversas regiones del país alebrestaban a las masas campesinas y esclavas. Es oportuno indicar que no todos estos conflictos protestatarios tuvieron un claro ni persistente contenido racial, ni abolicionista. Había, por otra parte, una mistificación ideológica que llevaba, por ejemplo, a pardos libres a apoyar en determinada coyuntura la causa antiesclavista, pero ellos mismos tenían esclavos a su servicio.

Ahora bien, el detalle sensible del cuerpo borrado de la foto (figuras 6, 7 y 8 ) pone en evidencia el complejo problema material y moral de la esclavitud no resuelta en una sociedad híbrida, ya no solo entre las masas esclavas, sino por sobre todo entre sectores libres no blancos: la cuestión del antiesclavismo fue tema candente entre los pardos y blancos pobres que al luchar por el fin de esa institución, se acercaban moralmente hacia ese otro y se producía una cercanía en términos raciales también. Pero, a la vez, la población de color fue estigmatizada como criminal y sujetos fuera de ley. Recordemos los no pocos bandidos que habitaron los llanos venezolanos y que la literatura se encargó de canonizar en novelas nada deleznables: Eduardo Blanco consagró con su novela Zárate (1882) a uno de los bandidos más importantes de los Valles de Aragua.

Paracomplicar más este contexto, los pardos libresy con ciertabonanzaeconómica (figuras 5 y 11) se vieron en una situación ambigua, atrapados entre las ansiedades raciales que criminalizaban a la gente de color, pero a la vez en un proceso de ascenso 
social que los impulsaba al reconocimiento e identificación moral a través de códigos formales de distinción (la tarjeta de visita), lo que acentuaba al mismo tiempo su deseo de distanciamiento del sector no solo esclavo, sino también de sus pares más oscuros de piel. Es decir, separarse lo más posible de aquellos otros que podían recordarles su propio pasado no tan lejano, y erradicar (encubrir) el eslabón somático o cultural entre la servidumbre de color y los nuevos señores: parecer blancos sin serlo. En este sentido, el universo visual de la fotografía fue construyendo un orden de "lo mismo", de semejantes dentro de ese paradigma estético, en el cual su relación con ese otro fue solamente instrumental, por decir puramente política y económica, en el cual la cuestión ética no se pudo articular.

No solo enfrentamos en el orden de los lenguajes simbólicos la construcción de la identidad de un sujeto que desea performar en el retrato su rostro como ciudadano (blanco), sino que además nos encontramos con una subjetividad doblemente fragmentada ( $s p l i t)$ y con una mayor urgencia de ver fijada su imagen en una narrativa estable. De acuerdo con Lacan, el sujeto en su etapa "infantil” se experimenta como cuerpo descentrado, que al mirarse en el espejo este le devuelve una imagen ideal de sí mismo unificada (recordemos el concepto unario del retrato de Barthes). La idea de un cuerpo completo y estabilizado (la fotografía es la tecnología ideal para ello) es indispensable para el proceso de identificación, pero a costa de la supresión de su realidad (denegación de su incoherencia o esquizofrenia) (Lalvani, 1982).

Podemos, por tanto, entender que dentro de este clima de alta inestabilidad, no solo en cuanto a claras políticas raciales, sino otras alteraciones sociales, como las masas campesinas desarraigadas y empobrecidas desde las guerras independentistas, los alzamientos de caudillos militares, el bandidaje descontrolado, pusieron sobre la mesa una guerra racial no explicitada, sino camuflada dentro de los lenguajes de las nomenclaturas partidistas. La historiografía tradicional ha preferido entender y explicar los conflictos de este periodo en términos de un enfrentamiento entre partidos, "conservador y liberal", escamoteando peligrosamente la naturaleza sociorracial del problema. Lo que se ha olvidado es que a lo largo de todo este medio siglo de guerras y rebeliones fue la circulación entre los sectores populares sublevados la consigna "muerte a los blancos", que se fue acallando con la subida al poder de Guzmán Blanco en las últimas décadas del siglo. Suponemos, por tanto, la difusión de ansiedades y miedos no explicitados entre toda la población, más ante el desdibujamiento de claras jerarquías basadas en diferencias étnico-sociales, y la precariedad de los naturales códigos de distinción. 
No es de extrañar entonces que el mismo Carreño, en su Manual dirigido a estas capas medias, se refiera en términos derogatorios a la servidumbre: recomienda no "reprenderlos severamente, no confundir la ira y la crueldad con el carácter enérgico", tampoco echarles en cara "sus defectos o deformidades naturales", ya que "por su ignorancia, y los muchos de los errores en que incurren los llevarían a mentir y a negar sus propios hechos", y "condenarnos a una agitación constante que turbaría nuestra propia tranquilidad” (Carreño s. f., 108). Era lugar común, en las ideologías raciales de la época, considerar a las poblaciones no blancas como cuerpos sociales naturalmente deformes, incontinentes, "bárbaros" irremediables, aparte de estigmatizarlos como criminales o sujetos contagiosos. No sería difícil imaginar que la permanente amenaza de estos sectores motivó a Carreño recomendar la atenuación de los castigos para prevenir cualquier exabrupto por parte del subalterno, a la par de tratar de mantener a la servidumbre fuera de la vista de las visitas y tertulias.

Entre dos aguas, estos sectores medios oscilaban, por un lado, entre el miedo a las turbas siempre en estado de sublevación, lo que las llevaba a distanciarse y separarse para distinguirse; por el otro, al aspirar a un estilo moderno cosmopolita, deseaban aparecer como sujetos "liberados" de las estructuras del pasado colonial, aunque las mantenían a despecho de su incómoda necesidad. Volvamos en este punto al tema del porte de las manos en los retratos (figuras 4 y 5): estas debían estar a la vista, expuestas con las uñas limpias y cortadas, es decir, manos liberadas del trabajo manual. Las manos en reposo decían de una clase liberada del trabajo manual asociado a la esclavitud, y que se distinguía porque se separaba del trabajo en sí y en su ocio acumularía capital por las vías de la explotación del trabajo del otro cuerpo que no salía en las fotos: ese cuerpo oprimido por una explotación precapitalista que se disimulaba, y reprimido por la cámara fotográfica.

Por ello mismo, los retratos donde la servidumbre aparece cubierta alegorizan las complejas contradicciones y "trastornos" de un inconsciente político de una clase a la hora de construir su representación simbólica. No solo oculta sus propias ansiedades raciales al posar como sujetos blancos para el proyecto de nación moderna, sino que oculta el lado oscuro de esa modernidad, la reproducción de la colonialidad en la república: es una clase que quiere aparecer self made, autosuficiente, no racista, que asciende por sus propios méritos — por ello el retrato es individual一, cuando en realidad está sostenida por un cuerpo laboral manumiso o esclavo al que necesita y teme a la vez. Lo que se encubre por tanto es la base esquizofrénica de esta contradicción, el "bulto" mismo de un problema que no puede ser enunciado. La 
violencia de lo no representado, de lo que no encuentra lugar en el lenguaje, en este caso visual, constituye el punto de ceguera de una clase que no puede reconocer la racialidad de su explotación ni de sus relaciones sociales.

La compulsión por el disciplinamiento de un cuerpo "bárbaro" - que debemos traducir como cuerpo mulato o pardo-y su materialización en los discursos de corrección invisibilizan a su vez la racialización del blanqueamiento (compárense figuras 2 y 4); el Manual oculta el carácter racial del cuerpo domesticado, porque ubica su centro de enunciación precisamente en el ángulo ciego de una sociedad que se piensa desracializada, que se piensa blanca o blanqueada, que combina ahora la transparencia de la identidad blanca con sus privilegios. Ha borrado de su retórica las jerarquías basadas en diferencias raciales (aunque la ansiedad racial siga operando); pero que repone ahora, promoviendo la ideología y valores blancos de "las buenas maneras de la gente bien", y que sin duda la fotografía de la tarjeta de visita ayudó a promover (Hill 1997; Hooks 1997; Doane y Bonilla-Silva 2003).9

Venezuela no acompasó en este renglón el género de las fotografías de tipos populares que, sin embargo, fueron producidas por centenares por fotógrafos reconocidos, como Cruces y Campa en México, Christiano Júnior en Brasil, y que en su formato de tarjetas de visita tuvieron mucha demanda en Europa. Hicieron un registro de los muchos oficios ejercidos por el sector popular para documentar las labores que iban a desaparecer con la modernización urbana (figura 12).

Aparte de su indudable carácter costumbrista y nostálgico, no menos estereotipador y folclorizante para el consumo de una clientela interesada en temas "exóticos" del nuevo mundo, al menos los fotógrafos de esas regiones incorporaron al campo visual las masas populares, de las que, como sabemos, a lo largo del XIX su representación fue siempre un tema espinoso y difícil: o se las demonizaba o idealizaba. A lo sumo en el caso venezolano algunos artistas como Martín Tovar y Tovar o viajeros como Camille Pizzarro dejaron esbozos al carboncillo de estos

9 Me permito conservar el inglés de la cita porque los conceptos son más efectivos: "Color-blind racial ideology has combined with the transparency of white identity and white privilege to create a new set of racial understanding [... In this 'color-blind' society, the prescription for dealing with racial issues is not to 'see' race and to claim that 'every is the same.' In other words, race is defined as an illegitimate topic for conversation [...] Given the transparency of 'whiteness' and of racial inequality, the 'denial' or 'strategic avoidance of race' is an effective political strategy for legitimizing the persistence of white hegemony [...] Anotherpolitical effect of color blindness and the transparency of 'whiteness' is the marginalization of the social and political claims of subordinate groups" (Doana y Bonilla-Silva 2003, 13). 


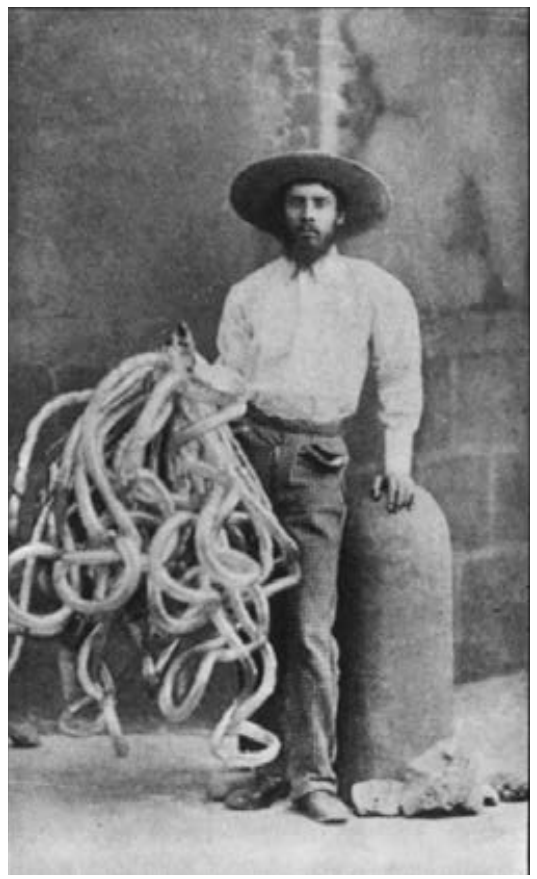

Figura 12. Tripero, de Cruces y Campa, alrededor de 1870

Nota. Es la colección de tipos populares más extensas y completa. Ofrece una visión populista y edulcorada del pueblo de la ciudad de México. Es un conjunto social homogeneizado, arreglado en poses artificiales para ser agradables a la vista del consumidor. Más bien se ha teatralizado la identidad ocupacional de cada personaje. Son fotos de estudio, y por tanto ha quedado borrada cualquier huella del contexto menos estetizado en que se desenvuelven estos oficios.

Fuente: cortesía Patricia Massé Zendejas.

sectores; cuerpos esbozados porque el trazo solo alcanzó a dibujar bultos sin rostro, si acaso el desempeño de algún oficio. ${ }^{10}$

De acuerdo también con la naturaleza del medio, las tarjetas de visita, al abaratarse los costos, fueron progresivamente invitando a otros sectores a retratarse, con lo cual también se flexibilizaron las exigencias de etiqueta y se relajaron las posturas. El marco fabricaba unidades serializadas discretas, y podía dejar de lado

10 A Martín Tovar y Tovar se le conoce como uno de los pioneros de la pintura histórica del siglo XIX. Sin embargo, se desempeñó como fotógrafo a su regreso a Caracas, donde fundó en 1865 un taller asociado con el fotógrafo José Antonio Salas, con quien trabajó hasta 1873. Ofrecían toda clase de trabajos fotográficos, inclusive "retratos mágicos", con las últimas técnicas traídas de Europa. Lo curioso es que no dejó fotografías de tipos populares; pero concursó tanto en la Exposición Universal de Londres, en 1862, y luego en la Exposición Universal de París, en 1867, con dos óleos: Llanero de Venezuela y Estudio de mulato ebrio. Por encargo del presidente Guzmán Blanco imprimió dos mil tarjetas de visita del prócer Andrés Ibarra. 
o fuera lo no asimilable. Por tanto, también la fotografía terminó siendo un dispositivo disciplinante y correctivo de las diferencias, porque estas, una vez dentro del cuadro o del marco, quedaban domesticadas, por no decir blanqueadas: el retrato en estos casos ejercía una nueva violencia, porque recortaba y descontextualizaba; neutralizaba el lugar politizado de estos otros sujetos no blancos y los asimilaba en su formato al archivo estandarizado de la burguesía (figura 13).

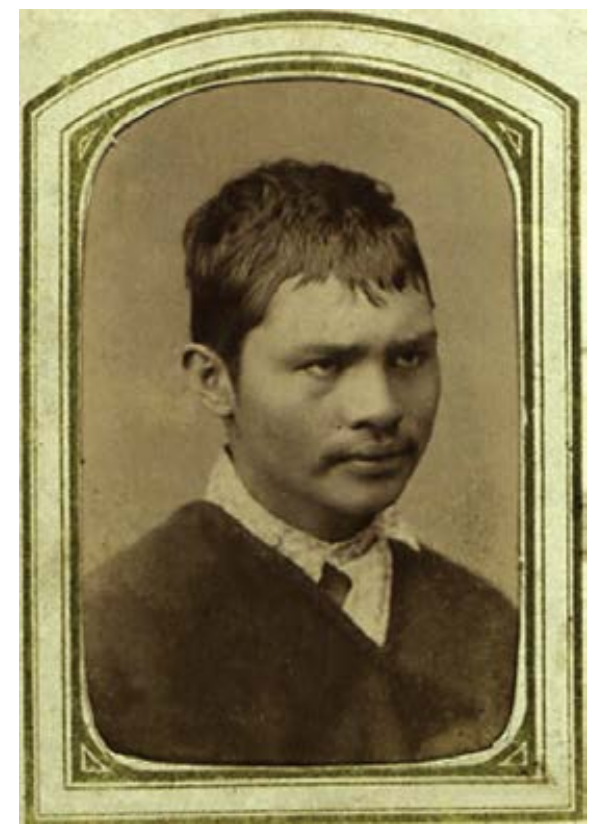

Figura 13. Muchacho no identificado, de Próspero Rey, alrededor de 1887

Sin embargo, este muchacho de probable origen indígena, con el cuello mal abotonado y con su poncho, expone al mismo tiempo la naturaleza conflictiva del campo de las representaciones visuales, porque el sujeto retratado está a mitad de camino en el esfuerzo de la tecnología por configurar su individuación (es decir, no llega a ser individuo del todo) y el retrato de un tipo popular, porque las marcas de su oficio han sido eliminadas; está por tanto desclasado. Podríamos arriesgar que aquello que se dejó fuera del marco, aquello que fue recortado o cubierto (los sujetos de color), es reintroducido en el campo visual, pero previamente retrabajado, es decir, blanqueado, o mejor, en proceso de blanqueamiento. Este excedente es la simulación de una performatividad burguesa; es su imitación diferida, y, por tanto, 
una resistencia: al esquivar su mirada del lente, preserva de algún modo su propia subjetividad, y no entrega lo que es; no ingresa en el estereotipo popular para el consumo masificado, pero al tiempo posa no del todo dentro del formato burgués.

A estas alturas podemos recordar lo propuesto por Michel Foucault, que toda época propone una concepción de lo que es posible ver dentro de las dinámicas del poder. Existe siempre una especie de “inconsciente positivo" del régimen ocular que determina lo que puede ser visto y lo que no. Todas las formas de visualización no son posibles al mismo tiempo. Cada periodo solo permite lo que puede ser visto de acuerdo con prácticas sociales contextualizadas, para poder ser pensado. Por tanto, hay mucho más represado en lo que se expone a la vista de lo que suponemos. Es decir, es mucho más lo que no se ve, que lo que es permitido ver.

Estimo que la fotografía en su formato de cartes de visites condensó en su modernidad tecnológica un doble dispositivo altamente rentable: el de proporcionar para las clases medias venezolanas en ascenso un blanqueamiento performático y su democratización a bajo costo. Hacerse un retrato de algún modo era participar del progreso, y del teatro de la "gente de bien".

\section{Bibliografía}

Abreu Xavier, Antonio de. 2011.La pasión criolla por el fashion: una historia de la pinta en la Venezuela del siglo XIX. Caracas: Alfa.

Alcibíades, Mirla. 2005. Manuel Antonio Carreño. Caracas: Biblioteca Biográfica Venezolana-El Nacional.

Barroso Alfaro, Manuel. 1995. Historia documentada de la fotografía en Venezuela. Caracas: Ediciones de la Presidencia de la República.

Barthes, Roland. 1990. La cámara lúcida: nota sobre la fotografía (trad. Joaquim SalaSanahuja). Barcelona: Paidós.

Bauer, Arnold J. 2001. Goods, Power, History: Latin America's Material Culture. Cambridge: Cambridge University Press.

Boulton, María Teresa. 1993. El retrato en la fotografia venezolana. Caracas: Fundación Galería de Arte Nacional.

Burguin, Victor, editor. 1982. Thinking Photography. Londres: McMillan Education. Carreño, Manuel Antonio. 1920. Manual de urbanidad y buenas maneras para uso de la juventud de ambos sexos. Bélgica: Bouret.

Cortés-Rocca, Paola. 2011. El tiempo de la máquina: retratos, paisajes y otras imágenes de la nación. Buenos Aires: Colihue S. R. L. 
Darrah, William C. 1981. Cartes de Visite in Nineteenth Century Photography. Gettysburg: W. C. Darrah.

Doane, Ashley Woody y Eduardo Bonilla-Silva, editores. 2003. White Out: The Continuing Significance of Racism. New York: Routledge.

Dorronsoro, Josune. 1981. Significación histórica de la fotografía. Caracas: Equinoccio, Universidad Simón Bolívar.

Freund, Gisele. 1946. La fotografía y las clases medias en Francia durante el siglo XIX (trad. Ma. Luisa Navarro). Buenos Aires: Losada.

Freund, Gisele. 1974. La fotografía como documento social (trad. Josep Elías). Barcelona: Gustavo Gili.

Gómez, Alejandro E. 2004. "Del affaire de los mulatos, al asunto de los pardos”. En Bolivarium. Instituto de Investigaciones Históricas, 301-321. Caracas: Universidad Simón Bolívar.

González, Gabriel. 2005. La fotografía en "El Cojo Ilustrado”. Caracas: Oasis.

González-Stephan, Beatriz. 1994. "Escritura y modernización: la domesticación de la barbarie”. Iberoamericana n. ${ }^{\circ}$ 166-167: 109-124.

González-Stephan, Beatriz. 1995a. "Las disciplinas escriturarias de la patria: constituciones, gramáticas y manuales”. Escritura. Revista de Investigaciones Literarias 5: $19-46$.

González-Stephan, Beatriz. 1995b. “Modernización y disciplinamiento: la formación del ciudadano. Espacio público y privado”. En Esplendores y miserias del siglo XIX: cultura y sociedad en América Latina, editado por Beatriz GonzálezStephan y Javier Lasarte, 431-451. Caracas: Monte Ávila-Equinoccio.

Hill, Mike, editor. 1997. Whiteness: A Critical Reader. New York: New York University Press.

Hooks, Bell. 1997. “Representing Whiteness in the Black Imagination”. En Displacing Whiteness, editado por Ruth Frankenberg, 165-179. Durham: Duke University Press.

Lalvani, Suren. 1996. Photography, Vision, and the Production of Modern Bodies. Albany: State University of New York Press.

Levine, Robert M. 1987. Windows on Latin America: Understanding Society through Photographs. Miami: North-South Center, University of Miami.

Levine, Robert M., editor. 1989. Images of History: Nineteenth and Early Twentieth Century Latin American Photographs as Documents. Durham: Duke University Press. 
Massé Zendejas, Patricia. 1998. Simulacro y elegancia en tarjetas de visita: fotografías de Cruces y Campa. México: INAH.

McCauley, Elisabeth Anne. 1985. A. A.E. Disdéri and the Carte de Visite Portrait Photograph. New Haven: Yale University Press.

McElroy, Keith. 1985. Early Peruvian Photography: A Critical Case Study. Ann Arbor: UMI Research Press.

Mitchell, W. J. T. 1994. Picture Theory. Chicago: University of Chicago Press.

Mitchell, W. J. T. 2005. What Do Pictures Want? The Lives and Loves of Images. Chicago: University of Chicago Press.

Molloy, Sylvia. 1994. "La política de la pose". En Las culturas de fin de siglo en América Latina, compilado por Josefina Ludmer, 128-138. Rosario: Viterbo.

Navarrete, José Antonio. 2009. “Las buenas maneras. Fotografía y sujeto burgués en América Latina durante el siglo XIX”. En Fotografiando en América Latina: ensayos de crítica histórica, 35-47. Caracas: Fundación para la Cultura Urbana. Orígenes de la fotografia en Venezuela. 1978. Caracas: Biblioteca Nacional.

Pérez Vila, Manuel. 1986. "El artesanado: la formación de una clase media propiamente americana”. Boletín de la Academia Nacional de la Historia 274: 325-341.

Pino Iturrieta, Elías. 2001. Elpaís archipiélago: Venezuela, 1830-1858. Caracas: Fundación Bigott.

Quintero, Inés. 2006. "Sobre la suerte y pretensiones de los pardos”. En Instituto de Estudios Hispanoamericanos, 327-345. Caracas: Universidad Central de Venezuela.

Romero, José Luis. 1976. Latinoamérica: las ciudades y las ideas. Buenos Aires: Siglo XXI.

Serrano, Eduardo. 1983. Historia de la fotografía en Colombia. Bogotá: Museo de Arte Moderno de Bogotá.

Silva, Armando. 1998. Álbum de familia: la imagen de nosotros mismos. Bogotá: Norma. Sosa Cárdenas, Diana. 2010. Los pardos: Caracas en las postrimerias de la Colonia. Caracas: Universidad Católica Andrés Bello.

Szinetar, Vasco, curador. 2008. El retrato en la colección. Caracas: Fundación para la Cultura Urbana.

Wright, Winthrop. 1990. Café con Leche: Race, Class, and National Image in Venezuela. Austin: University of Texas Press. 